\title{
KATARZYNA JAWORSKA-BISKUP
}

iD https://orcid.org/0000-0001-6696-3078

Uniwersytet Szczeciński

katarzyna.jaworska-biskup@usz.edu.pl

\section{PROBLEMY PRZEKŁADU TERMINOLOGII Z ZAKRESU PRAWA NA PODSTAWIE WYBRANYCH POLSKICH TŁUMACZEŃ SZTUK WILLIAMA SZEKSPIRA}

\section{Abstract \\ Problems of Translating Legal Language Based on William Shakespeare's Selected Plays}

The paper discusses major problems and issues of translating law and legal language into Polish as illustrated by selected examples from William Shakespeare's three plays: King Lear, The Merchant of Venice and Measure for Measure. The common feature of the plays is the context of the court and the trial. In King Lear, Shakespeare depicts a mock-trial of the main character's two daughters, Regan and Goneril. The crux of The Merchant of Venice is the proceedings instigated by Shylock against his debtor, Antonio. Measure for Measure features a summary trial of two local rogues, Froth and Pompey, who are brought to justice by the constable Elbow. A comparison of the English original lawembedded scenes with their Polish counterparts shows that Polish translators approached Shakespeare's legal lexicon differently. They frequently neutralised legal language or offered the equivalents that do not overlap with the source text. The different treatment of legal language by the translators results in various readings and interpretations of the original. The paper also provides a commentary on the basic concepts and institutions of English law in Shakespeare's analysed plays.

Keywords: law, William Shakespeare, translation

Słowa kluczowe: prawo, William Shakespeare, przekład 
Zagadnienie reprezentacji prawa w dziełach Williama Szekspira wzbudza żywe zainteresowanie wielu autorów. Na temat kwestii prawnych poruszanych przez tego klasyka angielskiej literatury powstały liczne publikacje, głównie w piśmiennictwie anglojęzycznym (np. Phillips 1972; Raffield, Watt 2008). Mimo że badania nad Szekspirem w Polsce mają tradycję sięgającą kilkudziesięciu lat, w rodzimej literaturze przedmiotu brakuje szczegółowych opracowań poświęconych terminologii z zakresu prawa w przekładach jego utworów na język polski.

Dzieła Szekspira są skarbnicą wiedzy na temat prawa materialnego i procesowego w Anglii czasów autora. Na szczególną uwagę zasługują opisy scen sądowych obfitujące w słownictwo specyficzne dla różnych gałęzi prawa. Odtworzenie prawniczego zasobu leksykalnego Szekspira stanowi nie lada wyzwanie dla tłumaczy, co ilustrują poniższe przykłady ${ }^{1}$ zaczerpnięte z trzech sztuk Stratfordczyka ${ }^{2}$ : King Lear (Król Lear), The Merchant of Venice (Kupiec wenecki) i Measure for Measure (Miarka za miarkę) $)^{3}$. Cechą wspólną przytoczonych poniżej fragmentów jest kontekst sądu i rozprawy sądowej. W przypadku Króla Leara mamy do czynienia z wymyślonym, wyreżyserowanym procesem karnym Goneryli i Regany. Na aktorów tego spektaklu obłąkany Lear wyznacza Edgara, Głupca i Kenta. W Kupcu weneckim przenosimy się do gmachu sądowego Doży, gdzie na naszych oczach rozgrywa się rozprawa wszczęta za sprawą skargi Shylocka. W trzeciej z analizowanych sztuk jesteśmy obserwatorami sceny sądowej w Wiedniu, w której konstabl Elbow stawia przed obliczem Angela i Escalusa, reprezentantów wiedeńskiego wymiaru sprawiedliwości namaszczonych na tę zaszczytną funkcję przez Księcia Vincentio, znanych w przestępczym półświatku Frotha i Pompeya.

1 W pracy ograniczam się do wybranych polskich przekładów wskazanych dzieł Szekspira. Pogłębione studium terminologii prawniczej angielsko-polskiej w oryginale i wszystkich polskich wersjach, zwłaszcza tych z przełomu XIX i XX wieku, na tle zmian prawnych i językowych oraz ewolucji tendencji translatorskich wymaga szerszego wywodu.

${ }^{2}$ Kanon szekspirowski jest pełen opisów procesów sądowych, żeby tylko wspomnieć o The Winter's Tale i Coriolanus. Refleksja nad prawem we wszystkich pomnikach literatury angielskiego renesansu wykracza poza wąskie ramy dyskusji prezentowanej na łamach tego artykułu. Korpus terminów objęty tutaj badaniem, w ocenie autorki, stanowi przegląd wybranych, acz znaczących problemów tłumaczeniowych mogących mieć bezpośrednie przełożenie na odbiór sztuki przez widza.

3 Wszystkie cytaty pochodzą z antologii: S. Wells, G. Taylor (red.) 2005. William Shakespeare. The Complete Works, Oxford: Oxford University Press. 
Rozważania na temat prawa w polskich przekładach Szekspira zacznę od analizy Króla Leara $(1605 / 1606)^{4}$. Akt trzeci tragedii zawiera przejmujące obrazy narastającego obłędu tytułowego władcy mitycznej Brytanii. W jednej z takich scen w wersji Quarto bohater przeprowadza fikcyjny proces córek, Goneryli i Regany. Lear rozpoczyna postępowanie od ustalenia zespołu właściwego do rozpoznania sprawy. W skład organu orzekającego wchodzą, zgodnie z dyspozycją króla, Edgar (,robed man of justice”), Głupiec („,his yokefellow of equity”) oraz Kent (3.6. 32-35). Przywołane angielskie zwroty nawiązują do dwóch filarów angielskiego prawa, a mianowicie common law i equity law ${ }^{5}$.

Początki kształtowania się common law w Anglii przypadają na wiek XII, głównie na okres rządów Henryka II (1154-1189) ${ }^{6}$. Wprowadzenie common law na obszarze całego kraju położyło kres lokalnej dywersyfikacji prawa zwyczajowego i umożliwiło budowanie sprawnego zinstytucjonalizowanego aparatu sądowo-administracyjnego. Z czasem jednak common law stało się niewystarczające do rozpatrywania wszystkich stanów faktycznych. Zarówno strony pokrzywdzone wyrokiem wydanym w sądach procedujących według common law, jak i te, które nie otrzymały skutecznej ochrony prawnej ze względu na brak odpowiedniej formuły procesowej inicjującej postępowanie miały w zwyczaju składać petycje do Lorda Kanclerza, jednego z najważniejszych urzędników w państwie, który orzekał zgodnie

4 Oprócz sceny quasi-procesu Goneryli i Regany Król Lear zawiera inne elementy prawa, przede wszystkim prawa rodzinnego i małżeńskiego (pojęcia dowry - posag, legitimate/illegitimate issue - potomek z prawego/nieprawego łoża), karnego (hue and cry - pogoń wszczęta za Edgarem podejrzanym o planowanie zamachu na życie ojca, Gloucestera, i podżeganie brata, Edmunda, do popełnienia tego czynu) i procesowego (proces Gloucestera, oskarżonego o zdradę, trial by battle - pojedynek Edgara i Edmunda). Także Głupiec, nieodłączny kompan Leara, czyni dygresje do prawa, jak chociażby niepochlebna opinia o prawnikach wyrażona w zdaniu: ,Then, like the breath of an unfee'd lawyer, you gave me nothing for't'" (1.4. 125-126). Ze względu na ograniczony zakres pracy, omawiam jedynie postępowanie sądowe w sprawie córek Leara.

${ }_{5}^{5}$ W szekspirowskiej literaturze przedmiotu panuje zgodny pogląd, że wyraz equity użyty w Królu Learze ma ścisłe znaczenie prawnicze. Szczegółową analizę equity w dziełach Szekspira przeprowadzili między innymi Phelps (1902: 9-10), Davis (1884: 246), Phillips (1972: 131), Sokol i Sokol (2004: 116-117; 1999: 417-439).

${ }^{6} \mathrm{~W}$ literaturze prawnohistorycznej podaje się, że proces tworzenia common law zaczął się tuż po najeździe Normanów w 1066 roku. Niektórzy historycy, na przykład John Hudson, podkreślają, że nie był to proces rewolucyjny, ale ewolucyjny, polegający na asymilacji i przekształcaniu wielu zastanych instytucji prawnych, które funkcjonowały obok tych ukształtowanych de novo. Opierając się na tym stanowisku, można zatem mówić o kontynuacji i ciągłości tradycji prawnych w Anglii (Hudson 2018). 
z equity law. Pod pojęciem equity law kryło się prawo stanowiące podstawę rozstrzygania spraw w The Court of Chancery (Sądzie Kanclerskim) oparte na zasadach słuszności. Rolą equity law była rewizja, korekta, uzupełnianie i łagodzenie sztywnych reguł prawa stosowanego w sądach common law. The Court of Chancery istniał formalnie do XIX wieku. Na mocy Judicature Act z 1873 roku został przekształcony w Chancery Division sądu The High Court of Justice (Baker 2007: 97-116; Marzec 2005: 195-212; Oleck 1951: 23-44; Ramjohn 2019: 40-57).

Na podstawie tych wyjaśnień można wnioskować, że w procesie Goneryli i Regany ma orzekać grono złożone z sędziego reprezentującego sąd związany normami common law i sędziego zasiadającego w The Court of Chancery, w którym procedura przebiegała według equity law. Ze względu na fakt, że obradom The Court of Chancery przewodził Lord Kanclerz, wyposażony w szereg uprawnień w zakresie rozpatrywania wnoszonych petycji i podejmowania ostatecznych rozstrzygnięć, nie wykluczone, że Szekspirowski Głupiec jest jego odpowiednikiem. Edgar natomiast, jak postulują liczni szekspirolodzy, jest przypuszczalnie alter ego The Chief Justice (Sędziego Przewodniczącego) The Court of King's Bench (Sądu Ławy Królewskiej) (Davis 1884: 246; Sokol, Sokol 1999: 436-439; 2006: 6-7; Halio 2005: 298) 7 .

Podział prawa na common law i equity law jest trudny do uchwycenia dla odbiorcy polskich przekładów Króla Leara. W polskojęzycznych wersjach tragedii Edgar, występujący w tej scenie w przebraniu Biednego Tomka, został przedstawiony jako: ,sędzia w powłóczystej todze” ( „Zasiądź no, sędzio w powłóczystej todze”, Tarnawski - Szekspir 1957: 140), „sędzia w todze” (,Ty, sędzio w todze, zajmuj swoje miejsce”, Siwicka - Szekspir 1956: 122; „Ty, sędzio w todze, zasiądź, gdzie należy”, Barańczak - Shakespeare 1991: 109), „mąż w szatach sądu” (,Zajmij twe miejsce, mężu w szatach sądu”, Słomczyński - Shakespeare 1979a: 119), „sędzia” („Udrapuj togę, / sędzio, i zajmij swoje miejsce”, Sito - Shakespeare 2004: 121) i „sędzia-prawnik w todze” (,Sędzio-prawniku w todze, zajmij miejsce”, Chwalewik - Szekspir 1964: 130). W przeciwieństwie do pozostałych autorów, którzy jednogłośnie mianowali Edgara sędzią, Słomczyński obrał literacką formę „mąż

${ }^{7}$ Mieszany skład orzekający był powszechnym zjawiskiem w angielskim prawie procesowym, co dokumentują liczne procesy, np. proces Marii Stuart z 1586 roku. Maria Stuart była sądzona przez zespół złożony z licznych dostojników, wśród których znajdowali się między innymi Lord Kanclerz, Sędzia Przewodniczący, Arcybiskup Canterbury (zob. Sokol, Sokol 1999: 437; 2006: 6-7; Bogucka 1990: 207). 
w szatach sądu" na opis tej postaci. W ostatnim z podanych ekwiwalentów zaproponowanych przez Chwalewika do wyrazu „sędzia” dodano drugi człon: ,prawnik”. Powstały w wyniku tego zabiegu zwrot „sędzia-prawnik” nawiązuje prawdopodobnie do rozróżnienia na sędziów zawodowych (sędziów prawników) i sędziów nieposiadających wykształcenia prawniczego, zwanych Sędziami Pokoju (Justices of the Peace).

Słów, którymi Lear określa Edgara, nie należy odczytywać w izolacji od scen wcześniejszych. W umyśle Leara widok Edgara przyodzianego jedynie w kawałek materiału przywodzi na myśl wizerunek najpierw filozofa, a w interesującym nas fragmencie - sędziego. W oryginale ubiór Edgara określony jest wyrazem blanket (dosłownie ,koc”). W polskich przekładach Edgar dla ukrycia tożsamości przypasa biodra „kołdrą” (Tarnawski - Szekspir 1957: 88), „szmatą" (Słomczyński - Shakespeare 1979a: 76; Sito - Shakespeare 2004: 75), „łachmanami” (Siwicka - Szekspir 1956: 81), „łachmanem” (Barańczak - Shakespeare 1991: 70). U Chwalewika czytamy jedynie o „opasaniu bioder" bez podania rodzaju okrycia (Chwalewik - Szekspir 1964: 87). Oczom Głupca jawi się natomiast sylwetka nagiego Edgara zakrywającego przyrodzenie „kołdrą” (Tarnawski - Szekspir 1957: 126), „derką” (Słomczyński - Shakespeare 1979a: 108), ,płachtą” (Siwicka - Szekspir 1956: 112), „opaską” (Chwalewik - Szekspir 1964: 119), „szmatą” (Barańczak Shakespeare 1991: 100), ,listkiem figowym” (Sito - Shakespeare 2004: 111). Niewątpliwie rzeczowniki takie jak „łachman” i „szmata” dosadnie ukazują upodlenie Edgara, społeczną i prawną degradację tego bohatera, wyrazem której jest wyjęcie spod prawa i wydziedziczenie przez ojca. Kołdra czy opaska są pozbawione takich asocjacji. Równocześnie jednak polski ekwiwalent powinien imitować togę sędziowską, zwłaszcza w kontekście potencjału scenicznego przekładu' . Wydaje się, że najwięcej podobieństw do stroju sędziego mają kołdra, płachta i derka. Trudno odnaleźć analogię między togą a opaską czy szmatą, a tym bardziej łachmanami i listkiem figowym. Dla potencjalnego widza sztuki obraz aktora wcielającego się w postać Edgara przechadzającego się po scenie w posuwistej kołdrze, płachcie czy zgrzebnej derce okalającej biodra jest czytelnym znakiem, że protagonista ten wchodzi w rolę sędziego w scenie szóstej aktu trzeciego. Pozostaje na koniec tego wywodu odnieść się ponownie do polskich deskrypcji Edgara. Zwrot „sędzia w powłóczystej todze” wiernie oddaje charakterystykę kołdry. Nazwa „sędzia w todze” połączona z łachmanem,

8 Por. komentarz Anny Cetery (2008: 192). 
łachmanami i opaską - a co dopiero z listkiem figowym - może tworzyć dysonans po stronie odbiorcy wywołany rozdźwiękiem pomiędzy obrazem a warstwą werbalną. Ze wszystkich podanych ekwiwalentów zwrot „mąż w szatach sądu” w zestawieniu z wizerunkiem Edgara przystrojonym w szmatę/derkę najbardziej trąci ironią i humorem. Efekt ten thumacz osiągnął poprzez kontrast między potocznym wyrazem „szmata” a podniosłym wyrazem „mąż”. Pomysł Słomczyńskiego na przekład tego zwrotu wzbogaca psychologizm Leara, który w całej sztuce rzuca oszczerstwami, groźbami, wyklina córki i ironizuje.

Głupiec w komentowanych spolszczeniach tragedii występuje jako: „szanowny kolega” („I ty też, jego szanowny kolego, / Chciej usiąść przy nim”, Siwicka - Szekspir 1956: 122), „kolega z trybunału” („I ty, kolego jego z trybunału, / Na ławie zajmij miejsce", Tarnawski - Szekspir 1957: 140), „ten, który z nim [Edgarem] dzieli / Trudy wyroków” („Siądź obok w ławie, ty, który z nim dzielisz / Trudy wyroków”, Słomczyński - Shakespeare 1979a: 119). W wersji Chwalewika Lear nakazuje Głupcowi zasiąść w ławie sędziowskiej słowami: „I ty z kolegą trudy dziel, siądź obok” (Chwalewik - Szekspir 1964: 130). Przekłady Słomczyńskiego i Chwalewika korespondują ze znaczeniem yokefellow (współpracownik, partner w wykonywaniu obowiązków, znoszeniu trudów) (Crystal, Crystal 2002: 507). Barańczak i Sito nadali towarzyszowi króla status ławnika („Ty, równie jak on szanowny ławniku, / Siądź obok niego”, Barańczak - Shakespeare 1991: 110; „A ty, / czcigodny ławniku - / na ławce, obok niego”, Sito Shakespeare 2004: 122) .

Obok Edgara i Głupca w sądzie ma zasiadać Kent, wierny dworzanin króla. W oryginale Lear zwraca się do Kenta w następujący sposób: „You are o’th' commission" (3.6. 34-35). Król czyni w tym fragmencie aluzje do posiedzeń specjalnych zespołów sędziowskich zwanych commissions orzekających w sprawach karnych (Crystal, Crystal 2002: 85). Trzeci

9 Warty odnotowania jest przekład Andrzeja Tretiaka z 1929 roku. W tym wydaniu Króla Leara Głupiec jest ,polubownym towarzyszem jego [Edgara] jarzma” (Tretiak - Szekspir 1929: 92). W tej wersji zaakcentowano wyraźnie związek Głupca z Sądem Kanclerskim w przypisie dołączonym do tego tłumaczenia, który wyjaśnia, że ,sąd of equity był właściwie instytucją sądów wyrównawczych, które łagodziły lub obostrzały wyroki, wydane według tzw. Common law (prawa zwyczajowego); zasiadali tam nie tylko prawnicy, lecz i laicy” (Tretiak - Szekspir 1929: 92). Użycie przymiotnika ,polubowny” w kontekście equity wydaje się jednak dyskusyjne. „Polubowny” w aspekcie wymiaru sprawiedliwości konotuje zakończenie sprawy w drodze porozumienia stron. Cechą equity, jak wyjaśniono wcześniej, było wyrokowanie na podstawie norm innych od tych stosowanych w sądach common law. 
z protagonistów powołanych przez Leara do rozpoznania sprawy Goneryli i Regany w przekładach Słomczyńskiego i Sity nazwany został ławnikiem: "Ty będziesz ławnikiem, / Więc zasiądź z nimi” (Słomczyński - Shakespeare 1979a: 119); „Ty będziesz drugim ławnikiem; / siądź obok” (Sito - Shakespeare 2004: 122). W wersji Tarnawskiego Kent pełni funkcję sędziego, analogicznie do Edgara i Głupca: „I wy również / Jesteście sędzią, więc zasiądźcie przy nich" (Tarnawski - Szekspir 1957: 140). Pozostali tłumacze jedynie wskazali na udział Kenta w rozprawie bez dokładnego określenia jego stanowiska procesowego: „Ty zaś do kompletu / Siądź z drugiej strony” (Barańczak - Shakespeare 1991: 110); „I ciebie także powołuję, zasiądź” (Chwalewik - Szekspir 1964: 130); „Należysz do sądu, / Więc usiądź także” (Siwicka - Szekspir 1956: 122).

W świetle zacytowanych fragmentów można dojść do konkluzji, że w zależności od tłumaczenia nad sprawą córek Leara pochyla się inne grono urzędników w służbie Temidy, na przykład u Tarnawskiego - trzech sędziów, Sity - sędzia i dwóch ławników, Słomczyńskiego - dwóch sędziów i ławnik. W przekładach Barańczaka i Słomczyńskiego w składzie orzekającym występuje ławnik, z tą różnicą, że u pierwszego autora jest nim Głupiec, a u drugiego z kolei Kent. W przeciwieństwie do Barańczaka i Słomczyńskiego, Sito powołał do udziału w rozprawie dwóch ławników, Głupca i Kenta. Z uwagi na to, że instytucja ławnika jest częścią polskiego systemu sądownictwa, przekłady prawdopodobnie odwzorowują postępowanie procesowe w kulturze docelowej.

Wybory tłumaczy implikują odbiór sceny procesu. W tekście wyjściowym postępowanie pierworodnej Goneryli i jej młodszej siostry Regany jest oceniane nie tylko z perspektywy zgodności z prawem, ale i zasad słuszności, co, jak zasugerowano wyżej, symbolizuje odpowiednio sylwetka Edgara i Głupca. Learowi przyświeca intencja wykazania nie tyle, że odtrącając ojca, córki postąpiły wbrew przepisom prawa, ile że naruszyły normy nakładające na dzieci obowiązek oddania szacunku leciwemu królowi pozostającemu w ich pieczy. Wniosek ten potwierdza fragment, w którym Lear nakazuje otwarcie ciała Regany i zbadanie, co kryje jej serce. Zmiana statusu Głupca z sędziego dokonującego wykładni prawa według equity law na ławnika zniekształca ponadto obraz tej postaci w całej sztuce. Głupiec jest głosem wygłaszającym prawdy o tym, co słuszne i prawe, przepowiadającym proroctwa, wytykającym Learowi jego błędy, głównie nieuzasadnione, pochopne rozparcelowanie królestwa pomiędzy dwie najstarsze córki i wyrugowanie z dziedzictwa najmłodszej Kordelii. Zwołując sąd, 
Lear określa tego bohatera przymiotnikiem sapiens, który oznacza osobę obdarzoną mądrością zakotwiczoną w doświadczeniu życiowym i wrodzoną umiejętnością dokonywania właściwych osądów.

Po tym, jak zostaje powołany skład wyimaginowanego sądu, stawiane są zarzuty Goneryli: „Arraign her first; 'tis Goneril” (3.6. 42). W prawie epoki Szekspira arraignment było etapem inicjującym postępowanie karne, podczas którego wzywano podejrzanego na posiedzenie sądowe, odczytywano akt oskarżenia oraz przyjmowano od osoby stawającej oświadczenie o przyznaniu bądź nieprzyznaniu się do zarzutów (Crystal, Crystal 2002: 23; Garner 2014: 104). Prawniczy sens tego terminu uległ zatarciu w przekładach Siwickiej (,Wezwijcie najprzód tę, to Goneril”, Siwicka - Szekspir 1956: 122), Słomczyńskiego (,Wezwijcie najpierw ją: to Goneryla”, Słomczyński - Shakespeare 1979a: 119) i Sity („Wprowadźcie pierwszą. To jest Goneryla”, Sito - Shakespeare 2004: 122). Na podstawie tych wyimków trudno wychwycić, że w przedmiotowej scenie dochodzi do wszczęcia procesu karnego. O postępowaniu sądowym piszą wprost Tarnawski („,Oskarżcie ją pierwszą, to Goneril”, Tarnawski - Szekspir 1957: 140), Barańczak („Goneryla stanie pierwsza przed sądem”, Barańczak - Shakespeare 1991: 110) i Chwalewik (,Stawi się podsądna Goneryla”, Chwalewik - Szekspir 1964: 130). Wyraz „oskarżyć” użyty przez Tarnawskiego jest dodatkowo silniej zabarwiony emocjami niż pozostałe odpowiedniki, przez co zwiększa się dramatyzm sceny. Wzburzony i rozżalony Lear pała rządzą oskarżenia Goneryli i Regany, nawołuje sąd do wymierzenia sprawiedliwości i ukarania córek za występki przeciwko ojcu. Prawniczy wydźwięk analizowanej sceny w przekładzie Chwalewika został wzmocniony przez dodanie wyrazu ,„podsądna” oznaczającego stronę postępowania sądowego. Zamysł postawienia córek w stan oskarżenia rodzi się w głowie Leara na początku sceny szóstej, co ilustruje zdanie: „I will arraign them straight” (3.6. 16). Chwalewik użył przestarzałego wyrazu ,zapozwać” (zob. Zajda 2001: 60), tłumacząc wypowiedź króla na „zapozwę je obie” (Chwalewik - Szekspir 1964: 129). Co ciekawe, odwołanie do pozywania zawiera także przekład Króla Leara autorstwa Zofii Siwickiej z 1951 roku. W tym wydaniu Lear komenderuje sąd, by pozwał Gonerylę: „Pozwijcie najprzód tę, to Goneril” (Siwicka Szekspir 1951: 308). W języku prawniczym ,pozwać”/,pozywać” opisuje czynność polegającą na złożeniu prywatnej skargi przez powoda przeciwko drugiej stronie zwanej pozwanym w procesie cywilnym. Przyjmując takie znaczenie tego terminu, można stwierdzić, że w obu polskich tekstach doszło do przekierowania procesu karnego w proces cywilny. Należy jednak 
odróżnić termin ,pozwać” we współczesnym, stricte cywilistycznym znaczeniu od ujęcia historycznego. W dawnym prawie polskim nie istniało rozgraniczenie na postępowanie w sprawach karnych i cywilnych. Pozywanie było wówczas formalnym aktem wezwania osoby do stawiennictwa w sądzie. Postępowanie sądowe wszczynała skarga osoby pokrzywdzonej lub jej najbliższych. Doręczenia pozwu, a zatem pozywania, dokonywał komornik, a od XVI wieku woźny na polecenie sędziego (Vetulani 1925; Lizisowa 1995: 198-200; Bardach et al. 2009: 192). Możliwe, że Chwalewik i Siwicka użyli odpowiednio wyrazów ,zapozwać” i „,pozwać” w znaczeniu wezwania na rozprawę, a nie wniesienia skargi przez osobę prywatną w sprawach cywilnych.

Podejmując tematykę recepcji prawa w dziełach Szekspira, nie można nie wspomnieć o Kupcu weneckim (1596/1597). Sztuka koncentruje się na sporze prawnym między lichwiarzem Shylockiem a kupcem Antoniem. W scenie trzeciej pierwszego aktu przysłuchujemy się rozmowie Bassania i Shylocka, której tematem jest pożyczka w wysokości 3000 dukatów. Wymieniona kwota jest przeznaczona na pokrycie kosztów wyprawy Bassania do Belmontu, gdzie wenecjanin konkuruje wraz z innymi zalotnikami o względy urodziwej i posażnej Porcji. Układ między Bassaniem a Shylockiem, jak dowiadujemy się z tej sceny, ma być zabezpieczony poręczeniem Antonia, co oznacza, że jeśli dłużnik główny (Bassanio) nie spełni zobowiązania w wyznaczonym terminie, wierzyciel (Shylock) będzie mógł dochodzić wymagalnego roszczenia od poręczyciela (Antonia). Użyty wielokrotnie przez Shylocka i Bassania zwrot to be bound sugeruje stosunek rękojmi. Zwracając się osobiście do Antonia, Shylock nakłania kupca do podpisania single bond. W literaturze przedmiotu istnieją różne interpretacje tego prawniczego terminu. Single bond może oznaczać rewers podpisany wyłącznie przez dłużnika głównego bez wsparcia poręczycieli, którzy w razie zwłoki w spłacie długu odpowiadają swym majątkiem (Raffel 2006: 31). Inni krytycy jedynie podają, że single bond dotyczy zwykłej umowy zawierającej zobowiązanie do zapłaty długu w określonym terminie (Watts 2006: 111). W piśmiennictwie poświęconym sztuce można spotkać także stanowisko, że single bond, w odróżnieniu od double bond, opisuje dokument bez dodatkowych warunków, na przykład zastrzeżenia o karze egzekwowanej w razie opieszałości dłużnika w terminowej spłacie zaciągniętego długu (Pollock, Maitland 1898: 225; Moelwyn Merchant 1967: 177; Sokol, Sokol 2004: 39-40; Halio 2008: 125). Ostatecznie, po dłuższych pertraktacjach i wymianie wzajemnych uszczypliwości, w obecności notariusza 
dochodzi do zawarcia umowy obwarowanej osobliwą karą, zapisaną, jak to określa Shylock, dla żartu (in a merry sport). Strony zastrzegają, że jeśli zobowiązanie nie zostanie spełnione w terminie trzech miesięcy od przystąpienia do układu, Shylock nabędzie prawo do funta ciała Antonia odciętego w miejscu wybranym przez lichwiarza. Po upływie wskazanego terminu Shylock kieruje kroki prawne przeciw Antoniowi. Sprawa trafia na wokandę sądu Doży, który zwołuje posiedzenie mające rozstrzygnąć racje obu przeciwników procesowych ${ }^{10}$.

Na dowód zawartej umowy Shylock przedkłada w sądzie bond, dokument potwierdzający zobowiązanie. W czasach elżbietańskich bond był powszechnie stosowanym instrumentem prawnym chroniącym wierzyciela na wypadek uchybienia terminowej spłaty długu przez dłużnika (Baker 2007: 323-326; Sokol 1992: 60-67; Sokol, Sokol 2004: 36-41). W drugim znaczeniu bond denotuje zobowiązanie. W kontekście sztuki Szekspira bond nabiera szczególnego znaczenia. Więź obligacyjna łączy nie tylko Shylocka i Antonia, ale także pozostałych bohaterów. Poprzez ucieczkę z domu rodzinnego w towarzystwie Lorenza Jessika, córka Shylocka, łamie child/ parent bond. Bassanio, nie dotrzymując obietnicy zachowania pierścienia podarowanego mu przez Porcję, obchodzi marital bond. Podobnie Gracjano ochoczo oddaje pierścień otrzymany od Nerissy. W polskich wersjach językowych bond występuje jako „oblig” (Brandstaetter), ,rewers” (Słomczyński), „weksel” (Kamiński), „zastaw”, „zobowiązanie”, „dokument” (Barańczak).

Decyzją Doży postępowanie zostaje odroczone do czasu przedstawienia opinii przez Bellaria, doktora prawa z Padwy. Jak wcześniej zauważyli inni autorzy, Bellario jest przedstawicielem elitarnej klasy prawników zwanych civil doctors, chlubiących się gruntownym wykształceniem w dziedzinie prawa rzymskiego i kanonicznego (Korporowicz 2014: 173-187). W Anglii civil lawyers zasiadali między innymi w The Court of Chancery, The Court of Requests i sądach kościelnych. Civil lawyers byli zrzeszeni w Doctors' Commons. Chcąc dostąpić zaszczytu członkostwa w tej grupie, aplikanci musieli posiadać dyplom potwierdzający ukończenie studiów prawniczych i doktorat z prawa rzymskiego. Inaczej wyglądała edukacja common lawyers, adeptów prawa orzekających w sądach common law. Kształceniem tych

${ }^{10}$ Na temat sceny procesu w Kupcu weneckim zob. między innymi Brune (1914: 19-34) i Phillips (1972: 91-118). Por. polemikę Posnera (2013) i Frieda (2013) odnośnie do słuszności roszczenia Shylocka w świetle treści umowy i przepisów prawa. 
prawników zajmowały się izby zwane Inns of Court (Marzec 2008: 47-48; 2003: 213-230; 2015: 20-29). Nie bez znaczenia jest także fakt, że Bellario pochodzi z Padwy. W epoce renesansu Padwa była ważnym ośrodkiem prawa rzymskiego i kanonicznego; przyciągała wielu Anglików, dla których była przepustką do kariery w organach administracji i sądownictwa w charakterze adwokatów, dyplomatów, osobistych doradców czy sekretarzy. Obok kształcenia studentów, ośrodek padewski skupiał wybitnych znawców prawa rzymskiego i kanonicznego, którzy wspomagali sądy wiedzą i doświadczeniem prawniczym (Woolfson 1998: 39-72).

Do sądu przybywa Porcja przebrana za Baltazara, uczonego w prawie doktora (,a young doctor of Rome”), rzekomego wysłannika Bellaria. Po ustaleniu stron i zapoznaniu się z meritum sprawy, Porcja zwraca się do Shylocka następującymi słowami: „Of a strange nature is the suit you follow, / Yet in such rule that the Venetian law / Cannot impugn you as you do proceed" (4.1.174-176). Suit (proces, postępowanie, żądanie) przetłumaczono jako „pozew” i ,powództwo”: „Zaiste, dziwne jest twoje powództwo, / Lecz w takim brzmieniu, że weneckie prawo / Twoim żądaniom nie może zaprzeczyć” (Brandstaetter - Szekspir 1953: 120); „Przedziwny jest ów pozew, który wniosłeś. / Lecz tak ujęty, że prawo weneckie / Nie może twego działania powstrzymać" (Słomczyński - Shakespeare 1979b: 112); „Pozew, który wniosłeś, / Jest niecodzienny, lecz weneckie prawo / Nie kwestionuje jego legalności” (Barańczak - Shakespeare 1992: 244); „Twoje powództwo jest dość osobliwe, / Lecz skoro zgadza się z weneckim prawem, / Musi starannie zostać rozpatrzone" (Kamiński - Shakespeare 2015: 162). W języku potocznym oba wyrazy używane są często zamiennie. W nauce prawa dominuje jednak pogląd, że pozew odnosi się do pisma procesowego wszczynającego postępowanie w sprawach cywilnych. Powództwo natomiast dotyczy treści pozwu, a dokładnie roszczenia/skargi powoda. Powództwo ma charakter środka procesowego służącego ochronie praw podmiotowych jednostki przed sądem (Dubisz 2003: 787, 815; Batorski 2000a: 732-734; 2000b: 736-738). Wydaje się, że w sztuce Szekspira chodzi o żądanie/skargę Shylocka, a nie dokument (por. Crystal, Crystal 2002: 430). Próżno także szukać w tekście oryginalnym śladów złożenia przez Shylocka pozwu w sądzie weneckim.

Shylock z uporem domaga się kary umownej. Porcja wyjaśnia lichwiarzowi, że jego roszczenie o wycięcie funta ciała Antonia będzie zaspokojone pod warunkiem, że nie spowoduje uronienia nawet jednej kropli krwi dłużnika. W przeciwnym razie majątek wierzyciela zostanie skonfiskowany 
przez państwo. Shylock ze zdziwieniem pyta, czy tak rzeczywiście stanowi prawo: „Is that the law?” (4.1. 311). Porcja udziela mu następującej odpowiedzi: „Thyself shalt see the act” (4.1. 312). Mimo zapewnień, młody doktor prawa nie zdradza Shylockowi, jaka podstawa prawna kryje się pod wyrazem act. Polscy thumacze nie są zgodni co do interpretacji słów kobiety. Słomczyński użył literalnego ekwiwalentu ,akt”: „Akt ów sam zobaczysz” (Słomczyński - Shakespeare 1979b: 119). W języku polskim „akt” ma szerokie znaczenie. Wyraz ten odnosi się do dokumentu urzędowego (np. akt notarialny, akta stanu cywilnego), aktu normatywnego czy aktu oskarżenia (zob. Kalina-Prasznic 2000: 21-29). Interesujący mnie passus u Barańczaka otrzymał inne brzmienie: „Służę ci kodeksem” (Barańczak - Shakespeare 1992: 251). Obrany przez tego autora termin „kodeks”, pochodzący od łacińskiego codex (księga, zbiór prawa), definiuje się jako zbiór przepisów regulujących określoną dziedzinę życia społecznego (Dubisz 2003: 350; Gromski 2000: 351). Kodeks budzi skojarzenia ze zbiorami prawa rzymskiego i kanonicznego. Jak zaznaczono wyżej, Bellario i podszywająca się pod Baltazara Porcja używają tytułu doktora prawa. W liście przesłanym Doży Bellario informuje, że wraz z Baltazarem przestudiowali wiele ksiąg w ramach przygotowań do rozprawy sądowej. Treść listu sugeruje uczestnikom postępowania, że Porcja, wzorem mistrza z Padwy, opiera argumentację wyłuszczoną na sali sądowej na myśli prawniczej zawartej w zbiorach prawa rzymskiego i doń czyni odniesienia, gdy zakazuje rozlewu krwi Antonia podczas wycinania funta jego ciała przez Shylocka. Kodeks rodzi także aluzje do konkretnego aktu normatywnego, choćby określonej ustawy karnej obowiązującej rzekomo w Wenecji, która, zgodnie z wykładnią Porcji, penalizuje rozlew chrześcijańskiej krwi. Niewykluczone, że thumacz zastosował termin dobrze znany polskiemu odbiorcy, bowiem w systemie prawnym civil law, do którego zalicza się polskie prawo, kodeksy, czy to prawa materialnego, czy procesowego, są jednym z podstawowych źródeł prawa. U Brandstaettera czytamy: „Wskażę ci artykuł” (Brandstaetter-Szekspir 1953: 128). Można domniemywać, że tłumacz miał na myśli jednostkę redakcyjną ustawy. Tłumaczenie Kamińskiego nie wskazuje, o jakie źródło prawa chodzi Porcji. Na pytanie Shylocka o prawo będące podstawą rozstrzygnięcia Porcja odpowiada wymijająco: „Przeczytasz je sobie" (Kamiński - Shakespeare 2015: 170). Z jednej strony taka projekcja tego fragmentu uwydatnia luki w wiedzy prawniczej Porcji, która nie potrafi precyzyjnie wyjaśnić zdumionemu Shylockowi, jakie prawo zabrania mu realizacji umowy. $Z$ drugiej strony przytoczone tłumaczenie wyraźnie 
akcentuje negatywny, lekceważący stosunek Porcji do powoda. Można odnieść wrażenie, że Porcja Kamińskiego jest mniej skora do podania aktu prawnego mającego zastosowanie w sprawie zawisłej przed sądem weneckim niż Porcja Barańczaka, która oferuje Shylockowi egzemplarz kodeksu, i Porcja Brandstaettera, gotowa zacytować konkretny artykuł ustawy.

W ramach dygresji należy wspomnieć, iż wgląd w polskie tłumaczenia utworów Szekspira pokazuje, że wśród ich autorów nie ma konsensusu co do przekładu nazw źródeł prawa. Za przykład można podać termin decree użyty przez dramaturga w kilku fragmentach Kupca weneckiego. Termin decree oznaczał pierwotnie wyrok zgodny z equity law, w odróżnieniu od judgement, wyroku kończącego postępowanie w sądach procedujących według common law (Garner 2014: 497-498) ${ }^{11}$. Obecność pojęć właściwych equity law w sztuce skłoniła niektórych autorów do wysunięcia hipotezy, że scena procesu jest refleksem ścierania się norm equity law z normami common law (np. MacKay 1964: 371-375) ${ }^{12}$. W rodzimych tłumaczeniach mowa jest o prawie, ustawie i dekrecie. W zależności zatem od doboru odpowiednika sens oryginalnej wypowiedzi zostaje zmodyfikowany.

W scenie końcowej procesu Porcja powołuje się na prawo określane w literaturze krytycznej jako „Alien Statute” (Kornstein 1994: 79-82; Weisberg 2008: 293-295) ${ }^{13}$, zgodnie z którym zamach na życie obywatela Wenecji przez cudzoziemca skutkuje karą śmierci i przepadkiem mienia. Warto zwrócić uwagę na brzmienie oryginału: „It is enacted in the laws of Venice” (4.1. 345). Brandstaetter pisze: „W prawie weneckim jest taka ustawa" (Brandstaetter - Szekspir 1953: 130). Słomczyński dokonał innego przekładu: „Jest zapisane w ustawach Wenecji” (Słomczyński - Shakespeare 1979b: 121). Tekst Słomczyńskiego daje nam do zrozumienia, że norma prawna sankcjonująca próbę zabójstwa obywatela Wenecji przez cudzoziemca jest rozproszona w wielu aktach prawnych. Barańczak użył wyrazu „,klauzula”: „W prawach Wenecji jest taka klauzula” (Barańczak - Shakespeare

11 We współczesnym angielskim języku prawniczym decree ma szeroki zakres znaczeniowy. Słowniki angielsko-polskiej terminologii prawniczej odnotowują takie odpowiedniki, jak rozporządzenie, zarządzenie, dekret (zob. Myrczek 2005: 48).

12 Por. alternatywne stanowisko wyrażone w pracach Bilella (2007: 109-126) oraz Sokol i Sokol (1999: 417-439).

13 Alien w języku angielskim oznacza obcego, odmiennego, osobę odstającą od grupy ze względu na własne przekonania, pochodzenie, przybysza z innej, odległej planety, co doskonale uwydatnia charakter prawa będącego podstawą rozstrzygnięcia Porcji. Mocą „Alien Statute" Shylock jest wykluczony ze społeczności weneckiej. 
1992: 253). Klauzula oznacza pewne zastrzeżenie, postanowienie lub warunek (Kalina-Prasznic 2000: 344-350; Dubisz 2003: 321). Przy pomocy Porcji tłumacz chce nam prawdopodobnie powiedzieć, że w prawie weneckim istnieje dodatkowy zapis różnicujący sytuację prawną cudzoziemców. Wreszcie u Kamińskiego czytamy: „Weneckie prawo wyraźnie powiada” (Kamiński - Shakespeare 2015: 172).

Biorąc za podstawę ustalenia dokonane w toku postępowania sądowego, Porcja orzeka, że lichwiarz ponosi winę usiłowania zabójstwa Antonia: „For it appears by manifest proceeding / That indirectly, and directly too, / Thou hast contrived against the very life / Of the defendant" (4.1. 355-359). Wskazując na Antonia, Porcja posługuje się terminem prawniczym defendant, który oznacza stronę postępowania sądowego, a mówiąc precyzyjnie: pozwanego w procesie cywilnym i oskarżonego w procesie karnym. W przekładzie Brandstaettera Porcja nazywa stronę pokrzywdzoną wprost po imieniu: „Dowody mamy w twym postępowaniu - / Że bezpośrednio i także pośrednio / Śmiałeś nastawać na życie Antonia" (Brandstaetter Szekspir 1953: 131). W podobny sposób fragment ten przełożył Kamiński: „Albowiem jawnie wynika z procesu, / Że bezpośrednio tudzież i pośrednio, / Godziłeś w życie owego Antonia” (Kamiński - Shakespeare 2015: 172). Słomczyński przetłumaczył defendant na „oskarżony”: „Gdyż jak wynika z jawnego procesu, / Oskarżonego tego chciałeś zgładzić, / Wprost bądź pośrednio" (Słomczyński - Shakespeare 1979b: 121). Barańczak wyraźnie wskazał, że Antonio ma status strony pozwanej: „Gdyż, jak widzieliśmy na własne oczy, / Godziłeś - bezpośrednio i pośrednio - / Na życie tego oto pozwanego" (Barańczak - Shakespeare 1992: 253). Przekład Barańczaka charakteryzuje wyraźna konsekwencja w utrzymaniu konwencji procesu cywilnego, głównie poprzez wielokrotne użycie terminów ,ppozwany”, ,pozew”, „pozwać”. Poza przypadkiem wskazanym wyżej, wyraz „pozwany” pojawia się jeszcze w trzech innych miejscach tego tłumaczenia. Na początku rozprawy Doża ubolewa nad faktem, że Antonio został pozwany przez Shylocka, przeciwnika podobnego do bestii niezdolnej okazać ani litości, ani miłosierdzia. Gdy Shylock przystępuje do odcięcia funta ciała Antonia, Porcja nakazuje mu najpierw sprowadzić chirurga celem zapobieżenia wykrwawienia się pozwanego. Kilka linijek dalej Porcja mówi o prawie Shylocka do wycięcia funta ciała z piersi pozwanego.

Proces kończy się ułaskawieniem Shylocka. Zgodnie z życzeniem Antonia, Doża pozwala zachować połowę mienia Shylockowi. Druga połowa masy majątkowej zostaje przekazana w powiernictwo (in use) Antoniowi, 
który obiecuje oddać ją Lorenzowi, zięciowi Shylocka, po śmierci lichwiarza. Zwrot in use nawiązuje do instytucji prawa angielskiego zwanej use, będącej pierwowzorem powiernictwa (trust). Istotą use było przeniesienie przez właściciela posiadanych przez niego dóbr na powiernika zwanego feoffee que use lub trustee z zastrzeżeniem, że pożytki będą pobierane przez beneficjenta określanego mianem cestui que use, a posługując się nazewnictwem angielskim, beneficiary. Beneficjentem był właściciel, wskazana przez niego osoba fizyczna lub instytucja kościelna. Use miało szerokie zastosowanie w okresie średniowiecza. Za pomocą use zabezpieczano byt najbliższej rodziny, głównie małoletnich dzieci niezdolnych do samodzielnego zarządu ziemią, na czas wyprawy misyjnej czy krzyżowej. Use wykorzystywano także jako środek pozwalający uchylić się od obowiązku zapłaty danin i innych dotkliwych podatków monarsze i panu feudalnemu, a także niechlubnie - w celu pokrzywdzenia wierzyciela. Powszechną praktyką przy ustanawianiu powiernictwa był zapis zawierający dyspozycję na wypadek śmierci. Instytucja use funkcjonowała do 1536 roku, w którym uchwalono Statute of Uses. Mocą tej ustawy beneficjent od tej pory nabywał pełne prawo do ziemi zarządzanej przez powiernika i tym samym odprowadzał wszelkie opłaty do skarbca państwowego (Baker 2007: 250-252; Sokol, Sokol 2004: 382-387; Ramjohn 2019: 43-46; Koranyi 1959: 135-137) ${ }^{14}$. Przenosząc te wyjaśnienia na grunt sztuki Szekspira, można stwierdzić, że w sądzie weneckim dochodzi do zawiązania powierniczego stosunku prawnego. Antonio przyjmuje na siebie funkcjęfeoffee. W literaturze krytycznej na temat Kupca weneckiego nie ma natomiast zgody co do tego, kto jest cestui que use. Ze słów Antonia nie wynika bowiem jednoznacznie, czy jest nim Shylock, Lorenzo czy sam Antonio (por. Sokol, Sokol 2004: 386; Weisberg 1998: 12-20).

Nie wszyscy polscy thumacze zachowali znaczenie angielskiego use. O powiernictwie, a dokładnie o „oddaniu w powiernictwo” drugiej połowy majątku Shylocka Antoniowi, mowa wprost w przekładach Słomczyńskiego i Barańczaka (Słomczyński - Shakespeare 1979b: 122; Barańczak - Shakespeare 1992: 254). Sens angielskiego powiernictwa rozmywa się w thumaczeniu Brandstaettera. Parafrazując ten przekład, Antonio zobowiązuje się oddać Lorenzowi po śmierci Shylocka „drugą połowę”, która mu ,przypadnie” (Brandstaetter - Szekspir 1953: 132). Próżno w tym przekładzie doszukać

14 Instytucja trustu zajmowała także grono polskich badaczy prawa. Zob. Zachariasiewicz (2016) i Michałowska (1996: 293-341). 
się aluzji do anglosaskiej instytucji use. Opierając się na wersji Kamińskiego, Antonio wyraża zgodę na zwrot połowy mienia Shylockowi pod warunkiem, że ten odda mu „drugą połowę majątku w dierżawę” (Kamiński - Shakespeare 2015: 173). Nie zagłębiając się w meandry prawa, dierżawa należy do innej kategorii stosunków prawnych niż wzmiankowany use.

Antonio nakazuje Shylockowi przyjąć chrzest oraz dokonać rozporządzenia na rzecz Lorenza i Jessiki. Prawnicze sformułowanie „,record a gift of all he dies possessed" (4.1.385-386) okazało się wyjątkowo problematycznym fragmentem sztuki nie tylko dla tłumaczy, ale także dla szekspirologów. Wnikliwa lektura tej części Kupca weneckiego nastręcza bowiem trudności w odszyfrowaniu dokładnego znaczenia przytoczonej frazy. Nie wiadomo, o jaki rodzaj czynności prawnej chodziło Szekspirowi. Gift może odnosić się zarówno do aktu darowizny, jak i testamentu (Phillips 1972: 99; Sokol, Sokol 2004: 386) ${ }^{15}$. W większości przekładów mowa jest o darowiźnie. W wersji Słomczyńskiego Shylock musi ,przyjąć chrzest niezwłocznie / I spisać (w sądzie tym) akt darowizny, / Którym przekaże w spadku wszystkie dobra / Synowi swemu Lorenzo i córce" (Słomczyński - Shakespeare 1979b: 122). Barańczak nadał tej wypowiedzi następujący kształt: „Po pierwsze, Shylock przyjmie zaraz chrzest; / Po drugie, spisze - tu, w tym samym sądzie - / Akt darowizny, w którym wszystkie dobra / Zapisze w spadku ${ }^{16}$ córce i zięciowi” (Barańczak - Shakespeare 1992: 254). Brandstaetter pisze: „Niechaj / Szajlok natychmiast przyjmie chrzest w kościele / I niech wystawi tu przed trybunałem / Akt darowizny, że wszystko po śmierci / Oddaje córce i swemu zięciowi” (Brandstaetter - Szekspir 1953: 132). Wyłom stanowi wersja Kamińskiego, który użył wyrazu „testament”, sugerując tym samym, że czynność prawna dokonana przez Shylocka nosi znamię zapisu testamentowego. W tym wydaniu Kupca weneckiego Shylock: „Musi się zaraz przechrzcić, a po drugie / Musi przed sądem sporządzić testament, / W którym swój cały majątek zapisze / Swemu zięciowi i córce" (Kamiński - Shakespeare 2015: 173-174). W kolejnej linijce mowa jest już jednak

15 Autorzy wskazują na wadliwość prawną wyroku Porcji. Na gruncie prawa zarówno darowizna, jak i testament wymagają oświadczenia woli osoby sporządzającej takie akty. W zaistniałej sytuacji Shylock zobowiązuje się do podpisania dokumentu rozporządzającego pod przymusem, co daje podstawę do jego unieważnienia. Zob. Phillips (1972: 99) i Brune (1914: 33-34).

16 Można się zastanawiać nad zasadnością użycia wyrazu „spadek”, który implikuje dziedziczenie testamentowe. 
o akcie darowizny: „Spiszcie więc akt darowizny” (Kamiński - Shakespeare 2015: 174).

Scenę rozprawy zamykają podziękowania skierowane dla Porcji przez Bassania: „Most worthy gentleman, I and my friend / Have by your wisdom been this day acquitted / Of grievous penalties" (4.1. 405-407). Bassanio posługuje się językiem typowym dla żargonu prawniczego, co ilustrują takie terminy, jak to acquit (zwolnić) i grievous penalties (ciężkie/dotkliwe kary/ sankcje karne). Nie wszystkim tłumaczom udało się uchwycić prawniczą wymowę oryginału ${ }^{17}$. Prawniczy wydźwięk zachowały jedynie przekłady Barańczaka („Czcigodny panie, ja i mój przyjaciel / Dzięki twej wiedzy zdołaliśmy ujść / Dotkliwej kary”, Barańczak - Shakespeare 1992: 256) i Brandstaettera („Dostojny panie, ja i mój przyjaciel / Dzięki twej wiedzy dziś uniknęliśmy / Dotkliwej kary”, Brandstaetter - Szekspir 1953: 134). Pozostałe tłumaczenia, takie jak „kary bolesne” u Słomczyńskiego („Czcigodny panie, dzięki twej mądrości, / Ja i przyjaciel mój, uniknęliśmy / Dziś kar bolesnych”, Słomczyński - Shakespeare 1979b: 123-124) czy „wielka opresja” u Kamińskiego („Szlachetny panie, mnie i przyjaciela / Swoją mądrością wybawiłeś dzisiaj / Z wielkiej opresji”, Kamiński - Shakespeare 2015: 175) cechuje neutralizacja dyskursu prawniczego. Warte refleksji są możliwe konsekwencje tej strategii dla recepcji i wymowy sztuki. Zastąpienie rejestru prawniczego leksemami nacechowanymi emocjonalnie, jak w przekładach Słomczyńskiego i Kamińskiego, wyraźnie eksponuje wątek uczucia Bassania i Antonia. W tych wersjach Kupca weneckiego realizacja umowy polegająca na zabiciu Antonia przez Shylocka byłaby dla Bassania opresją, boleścią, inaczej rzecz ujmując, niepowetowaną stratą. Bassanio już wcześniej otwarcie deklarował swoje przywiązanie do Antonia, wyznając, że życie przyjaciela jest mu droższe niż los świeżo poślubionej żony.

Dyskusja przeprowadzona do tej pory oscylowała wokół zawiłości przekładu angielskiej terminologii prawniczej. Z punktu widzenia inscenizacji teatralnej i prognozowanych kierunków interpretacji sceny procesu nie możemy zignorować informacji odnośnie do ubioru Nerissy przekazanej w didaskaliach. Przekład Barańczaka podaje, że Nerissa wchodzi na salę rozpraw w przebraniu sekretarza sędziego (Barańczak - Shakespeare 1992:

17 Do podobnych wniosków dochodzi Savenets (2011: 255-270). Jak zauważa autor, angielski zwrot grievous penalties został pozbawiony konotacji prawniczych w niektórych ukraińskich przekładach Kupca weneckiego. W opinii badacza, w odniesieniu do oryginalnego wyrażenia zastosowano zabieg tak zwanej poetyzacji, czyli nadano mu cechy języka poetyckiego. 
241). U Kamińskiego poznajemy bohaterkę w stroju sekretarza (Kamiński Shakespeare 2015: 158). W wersji Słomczyńskiego Nerissa jest przebrana za pomocnika adwokata (Słomczyński - Shakespeare 1979b: 109). Brandstaetter posłużył się w tym miejscu archaizmem ,dependent” (Brandstaetter Szekspir 1953: 117). Dependent, znany także jako torbifer (od noszenia torby za swoim patronem), oznaczał niegdyś aplikanta, sekretarza, pomocnika w kancelarii adwokackiej lub notarialnej. Urzędnik ten prowadził kancelarię, opracowywał akta patrona, asystował swojemu pryncypałowi w trakcie rozprawy, doręczając mu niezbędne dokumenty i akty prawne (Dubisz 2003: 587; Góralski 1988: 222-223).

Wybory tłumaczy zmieniają wydźwięk aktu czwartego. Przekłady Słomczyńskiego i Brandstaettera sugerują widzowi sztuki, że Porcja przybywa do Wenecji w charakterze pełnomocnika Antonia broniącego jego interesów w toczącym się sporze prawnym. Opierając się na wersji Barańczaka, dochodzimy do wniosku, że Porcja jest sędzią powołanym przez Dożę, aby rozstrzygnął konflikt między zwaśnionymi stronami w sposób obiektywny i zgodny z prawem. Warto przypomnieć, że uczestnicy procesu zwracają się do Porcji wyrazem judge (sędzia) i ponaglają rzekomego doktora prawa do wydania judgement (wyroku). Tłumaczenie Kamińskiego pozwala odbiorcy samodzielnie ocenić, jaką rolę procesową - sędziego czy obrońcy Antonia - odgrywa w sądzie Porcja.

$\mathrm{Na}$ koniec rozważań o przekładzie terminologii prawniczej w dziełach dramaturga ze Stratfordu przyjrzyjmy się scenie procesu w sztuce Miarka za miarkę (1603/1604). W akcie drugim, scenie pierwszej Elbow, sprawujący urząd konstabla, w ręce namiestnika Angela i sędziego Escalusa przekazuje Pompeya i Frotha. Informując Angela i Escalusa o zatrzymaniu sprawców, Elbow używa słowa benefactors (darczyńcy): „I do lean upon justice, sir; and do bring in here before your good honour two notorious benefactors" (2.1.46-48). Angelo natychmiast poprawia konstabla, wyjaśniając, że chodzi mu zapewne o podobnie brzmiące malefactors (przestępcy): „Benefactors? Well, what benefactors are they? Are they not malefactors?" (2.1. 49-50). Przymiotnik notorious opisuje sprawców notorycznie łamiących przepisy prawa; wedle prawniczej nomenklatury, w warunkach recydywy. W przekładzie Chwalewika nie ma ani śladu terminologii prawniczej, ani zamierzonego przez Szekspira efektu humorystycznego. „Sprawiedliwości służę, i przed sąd Waszej Wysokości dostawiam dwóch społecznych elementów”, mówi Elbow. Angelo odpowiada: „Elementów? Jakich elementów? Społeczne męty?" (Chwalewik - Szekspir 1958: 38). Zupełnie inaczej przedstawia ten 
fragment przekład Słomczyńskiego. W tej odsłonie Miarki za miarkę słowa Elbowa/Łokcia są następujące: „Wsparty na sprawiedliwości, panie, przyprowadziłem tu przed waszą łaskawą czcigodność dwóch zatwardziałych dobroczyńców”. Na to Angelo: „Dobroczyńców? Cóż to za dobroczyńcy? A może złoczyńcy?" (Słomczyński - Shakespeare 1982: 36).

Na marginesie warto odnotować, że Elbow w przekładzie Słomczyńskiego nie figuruje na liście dramatis personae jako konstabl, ale jako ,pachołek księcia”, ,prostak”, „pachołek miejski”. Z tego przekładu polski czytelnik nie może wywieść, że Elbow jest funkcjonariuszem publicznym odpowiedzialnym za stosowanie prawa karnego. Pod angielskim terminem constable krył się przedstawiciel wymiaru sprawiedliwości wykonujący obowiązki prokuratorsko-policyjne na szczeblu lokalnym, takie jak między innymi pilnowanie ładu i porządku, wydawanie nakazu aresztowania, przedstawianie zarzutów karnych, egzekwowanie przepisów prawa karnego. Od kandydatów na to stanowisko oczekiwano specjalnych przymiotów, głównie nieskazitelnego charakteru, nieposzlakowanej opinii i empatii (Sokol, Sokol 2004: 59-66; Koranyi 1959: 115; Wall 1998: 14-15). Niewątpliwie Szekspirowski konstabl Elbow daleki jest od idealnego urzędnika państwowego stojącego na straży praworządności.

W toku indagacji wszystkich zebranych w sądzie wychodzi na jaw, że Pompey para się sutenerstwem na usługach niejakiej, owianej niesławą, Pani Overdone (Pani Przesadnej w wersji Słomczyńskiego). Bezpośrednim świadkiem procederu ponoć ma być żona Elbowa. W dalszej części sztuki dochodzi do kolejnych omyłek słownych zapoczątkowanych przez Elbowa, który tym razem myli przymiotnik respected z suspected: „First, an it like you, the house is a respected house; next, this is a respected fellow; and his mistress is a respected woman" (2.1. 155-157). Pompey podważa wiarygodność Pani Elbow, spiritus movens całego zajścia, twierdząc, że kobieta ma więcej na sumieniu niż on sam i jego kompan: „By this hand, sir, his wife is a more respected person than any of us all" (2.1.158-159). Na co reaguje Elbow: „Varlet, thou liest; thou liest, wicked varlet / The time is yet to come that she was ever respected with man, woman, or child" (2.1. 160-162). W odpowiedzi na te słowa Pompey insynuuje, że Elbow obcował z żoną, zanim stali się pełnoprawnym małżeństwem: „Sir, she was respected with him before he married with her" (2.1. 163-164).

Szekspirowski malapropizm respected (szanowana, poważana) / suspected (podejrzana) zanika w polskich przekładach. U Chwalewika Elbow mówi: „Że, po pierwsze, wielmożny panie, mamy ten dom w naszej rewerencji, po 
wtóre, i jego też mamy w rewerencji, a tak samo jest w rewerencji i jego chlebodawczyni”. Na te zarzuty Pompey ripostuje: „Rękę podnoszę, wielmożny panie, na świadectwo, że jego żona najbardziej godna rewerencji”. Elbow bierze w obronę żonę: „Łżesz, pachołku, łżesz, łapserdaku, nigdy nie była w rewerencji względem mężczyzny, kobiety czy dziecka”. Na co odzywa się Pompey: „Ale była względem niego w rewerencji, zanim jeszcze się pobrali" (Chwalewik - Szekspir 1958: 44). W wersji Słomczyńskiego z ust Elbowa wypływa inne zdanie: „Po pierwsze, za przyzwoleniem waszym, dom ten przynosi respekt; po drugie, on także przynosi respekt; a jego pani jest niewiastą, która przynosi respekt". Pompey rzuca podejrzenia na żonę Elbowa: „Na tę rękę, panie; jego żona jest bardziej respektowaną osobą niż ktokolwiek z nas”. Wywołuje to wzburzenie konstabla: „Kłamiesz, łajdaku! Kłamiesz, ty nikczemny łajdaku! Niedoczekanie twoje, aby kiedykolwiek respektowała się z mężczyzną, kobietą lub dzieckiem". Pompey odpowiada: „Panie, respektowała się z nim, zanim pojął ją za żonę” (Słomczyński Shakespeare 1982: 42-43).

Wzajemną wymianę inwektyw obu mężczyzn przerywa Escalus pytaniem: „Which is the wiser here, justice or iniquity?” (2.1. 165). Jak widać, znowu dochodzi do pomylenia equity z iniquity (niesprawiedliwość, występek). Dla angielskiego odbiorcy oba wyrazy kojarzą się ze wspomnianym wcześniej podziałem na dwa wymiary prawa angielskiego, common law i equity law. Polskie przekłady są pozbawione tych asocjacji. U Chwalewika czytamy: „I któż tu będzie mądrzejszy: sprawiedliwość czy występek? (Chwalewik - Szekspir 1958: 44). U Słomczyńskiego: „Któż jest tu mądrzejszy, Sprawiedliwość czy Bezeceństwo?” (Słomczyński - Shakespeare 1982: 43).

Rozjuszony Elbow grozi Pompeyowi, że wkroczy na drogę sądową przeciwko niemu z zarzutem o battery: „Prove this, thou wicked Hannibal, or I'll have mine action of battery on thee" (2.1. 171-173). Escalus wtrąca: „If he took you a box o'th' ear, you might have your action of slander too" (2.1. 174-175). Slander, mający odpowiednik w polskim zniesławieniu, polega na przypisaniu danej osobie zachowania lub cech, które naruszają jej cześć i dobre imię. Motywem działania sprawcy zniesławienia jest chęć poniżenia pokrzywdzonego w jego środowisku i podważenie doń zaufania (Sokol, Sokol 2004: 207-212; Garner 2014: 1600; Dubisz 2003: 731). W przypadku, o którym mowa, Elbow nie doświadczył od Pompeya przemocy fizycznej, która stanowiłaby przesłankę do kwalifikacji czynu jako battery (zob. Garner 2014: 182). Imputując, że żona Elbowa prowadzi rozwiązłe życie, 
Pompey, trzymając się ścisłej litery prawa, popełnia slander. Chwalewik nie zachował prawniczego kontekstu analizowanego fragmentu: „Dowody złóż, nędzny Hannibalu, a nie, to cię na kwaśne jabłko sądownie stłukę" (Chwalewik - Szekspir 1958: 45). Jedynie w przekładzie Słomczyńskiego zastosowano prawniczy ekwiwalent „pobicie”: „Dowiedź tego, bezecny Hannibalu, inaczej oskarżę cię o pobicie" (Słomczyński - Shakespeare 1982: 43). Co do angielskiego slander, obaj thumacze wybrali wyrazy o zbliżonym znaczeniu, ale należące do innej odmiany języka. W wersji Chwalewika odpowiednikiem slander jest „obmowa”: „A gdyby ci jeszcze dał po uchu, tobyś mógł sądownie skarżyć o obmowę" (Chwalewik - Shakespeare 1958: 45). Słomczyński dokonał innego przekładu rzeczonego fragmentu, obierając za ekwiwalent slander prawniczy termin „oszczerstwo”: „Gdyby cię palnął w ucho, mógłbyś go oskarżyć także o oszczerstwo” (Słomczyński Shakespeare 1982: 43).

Rozwiązania zastosowane przez obu tłumaczy nie pozostają bez wpływu na potencjał sceniczny sztuki i jej odbiór przez widza. Przekładowi omawianej sceny, który wyszedł spod pióra Chwalewika, można wytknąć nie tylko straty po stronie humoru i terminologii prawniczej. W tej wersji Miarki za miarkę zmienia się sposób obrazowania Elbowa. Dzięki komizmowi zarysowanemu w przywołanym fragmencie uwypuklone zostają przywary tego bohatera, zwłaszcza brak kompetencji w zakresie stosowania i wykładni prawa. Szekspirowski Elbow jest mało rezolutnym, niegrzeszącym inteligencją urzędnikiem państwowym. Jego literacki portret wtapia się w wizerunek całego społeczeństwa wiedeńskiego, siedliska bezprawia, wyuzdania i upadku moralnych wartości. Elbow wykreowany przez Chwalewika, w konfrontacji z Łokciem Słomczyńskiego, wydaje się postacią mniej wyrazistą, rubaszną i zabawną. W przekładzie Słomczyńskiego Łokcia wyróżnia nie tylko ignorancja prawa, ale, jak widać jaskrawo w scenie drugiej aktu trzeciego, cięty, wulgarny język.

Tematyka prawa dotycząca funkcjonowania wymiaru sprawiedliwości, zwłaszcza w aspekcie common law i equity law, prymatu prawa naturalnego nad prawem stanowionym, uprawnień jednostki do obrony praw podmiotowych, jak również słownictwo prawnicze nie były obce ani tym bardziej obojętne Szekspirowi. W swej bogatej twórczości autor zręcznie wykorzystywał terminologię prawa w scenach opisujących osobiste dramaty głównych bohaterów, jak to ma miejsce w przypadku obłąkanego Leara stawiającego przed fikcyjnym sądem wyrodne córki i osamotnionego w walce o spełnienie należnego zobowiązania Shylocka, nie wspominając 
o zabawnych potyczkach słownych Elbowa w Miarce za miarkę. Przeprowadzona w tym opracowaniu analiza uwydatniła problemy, jakie napotkali thumacze w konfrontacji ze słownictwem prawniczym w wybranych dramatach Szekspira, w dużej mierze mające swe źródło w nieprzekładalnych różnicach kulturowych między angielskim systemem common law a polskim civil law. Choć zaprezentowany przekrój trudności specyficznych dla przekładu Szekspirowskiego języka prawniczego nie wyczerpuje z pewnością zarysowanego tematu, rzuca pewne światło na recepcję prawa w polskich przekładach literatury tego autora.

\section{Bibliografia}

\section{Źródła podstawowe}

Halio J.L. (red.) 2005. William Shakespeare. The Tragedy of King Lear, Cambridge: Cambridge University Press.

— (red.) 2008. William Shakespeare. The Merchant of Venice, Oxford: Oxford University Press.

Raffel B. (red.) 2006. William Shakespeare. The Merchant of Venice, New Haven-London: Yale University Press.

Shakespeare W. 1979a. Wiernie spisane dzieje żywota i śmierci króla Leara i jego trzech córek, przeł. M. Słomczyński, Kraków: Wydawnictwo Literackie.

— 1991. Król Lear, przeł. S. Barańczak, Poznań: „W drodze”.

- 2004. Król Lear. Sonety, przeł. J.S. Sito, Warszawa: Polskie Media Amer.Com.

- 1982. Miarka za miarkę, przeł. M. Słomczyński, Kraków: Wydawnictwo Literackie.

— 1979b. Najwyborniejsza opowieść o kupcu weneckim, przeł. M. Słomczyński, Kraków: Wydawnictwo Literackie.

- 1992. Sen nocy letniej. Kupiec wenecki, przeł. S. Barańczak, Poznań: „W drodze”.

— 2015. Kupiec wenecki, przeł. P. Kamiński, Warszawa: Wydawnictwo W.A.B.

Szekspir W. 1929. Król Lir. Tragedja w pięciu aktach, przeł. A. Tretiak, Kraków: Krakowska Spółka Wydawnicza.

— 1951. Otello. Król Lir. Makbet, przeł. Z. Siwicka, Warszawa: Książka i Wiedza.

- 1956. Król Lir, przeł. Z. Siwicka, Warszawa: Państwowy Instytut Wydawniczy.

- 1957. Król Lear, przeł. W. Tarnawski, Wrocław, Kraków: Zakład Narodowy im. Ossolińskich.

— 1964. Król Lear, przeł. W. Chwalewik, Warszawa: Państwowy Instytut Wydawniczy.

- 1958. Miarka za miarkę, przeł. W. Chwalewik, Warszawa: Państwowy Instytut Wydawniczy.

— 1953. Kupiec wenecki, przeł. R. Brandstaetter, Warszawa: Państwowy Instytut Wydawniczy. 
Wells S., Taylor G. (red.) 2005. William Shakespeare. The Complete Works, Oxford: Oxford University Press.

\section{Literatura naukowa}

Baker J.H. 2007. An Introduction to English Legal History, Oxford: Oxford University Press.

Bardach J., Leśnodorski B., Pietrzak M. 2009. Historia ustroju i prawa polskiego, Warszawa: LexisNexis.

Batorski D. 2000a. Powództwo, w: U. Kalina-Prasznic (red.), Encyklopedia prawa, Warszawa: C.H. Beck, s. 732-734.

- 2000b. Pozew, w: U. Kalina-Prasznic (red.), Encyklopedia prawa, Warszawa: C.H. Beck, s. 736-738.

Bilello T.C. 2007. Accomplished with What She Lacks: Law, Equity, and Portia's Con, w: C. Jordan, K. Cunningham (red.), The Law in Shakespeare, Basingstoke-New York: Palgrave Macmillan, s. 109-126.

Bogucka M. 1990. Maria Stuart, Wrocław: Zakład Narodowy im. Ossolińskich. Brune C.M. 1914. Shakespeare's Use of Legal Terms, London: W. Straker.

Cetera A. 2008. Enter Lear: The Translator's Part in Performance, Warszawa: Wydawnictwa Uniwersytetu Warszawskiego.

Crystal D., Crystal B. 2002. Shakespeare’s Words: A Glossary and Language Companion, London: Penguin Books.

Davis C.K. 1884. The Law in Shakespeare, St. Paul: West Publishing Company.

Dubisz S. (red.), 2003. Uniwersalny słownik języka polskiego, Warszawa: Państwowe Wydawnictwo Naukowe.

Fried C. 2013. Opinion of Fried, J., Concurring in the Judgment, w: B. Cormack, M.C. Nussbaum, R. Strier (red.), Shakespeare and the Law: A Conversation among Disciplines and Professions, Chicago-London: University of Chicago Press, s. 156-163.

Garner B.A. (red.), 2014. Black's Law Dictionary, St. Paul: Thomson Reuters.

Gromski W. 2000. Kodeks, w: U. Kalina-Prasznic (red.), Encyklopedia prawa, Warszawa: C.H. Beck, s. 351.

Góralski Z. 1988. Urzędy i godności w dawnej Polsce, Warszawa: Ludowa Spółdzielnia Wydawnicza.

Hudson J. 2018. The Formation of the English Common Law: Law and Society in England from King Alfred to Magna Carta, London-New York: Routledge.

Kalina-Prasznic U. (red.), 2000. Encyklopedia prawa, Warszawa: C.H. Beck.

Koranyi K. 1959. Powszechna historia państwa i prawa, tom III, Warszawa: Wydawnictwo Prawnicze.

Kornstein D.J. 1994. Kill all the Lawyers? Shakespeare's Legal Appeal, Princeton, New Jersey: Princeton University Press.

Korporowicz Ł.J. 2014. Doktorzy prawa $w$ dwóch angielskich komediach epoki renesansu, ,Studia Prawnicze KUL” 1(57), s. 173-187. 
Lizisowa M.T. 1995. Podstawowe terminy prawne w Statutach Staropolskich na tle słowiańskim. Studium semantyczne, Kraków: Wydawnictwo Naukowe WSP.

MacKay M. 1964. The Merchant of Venice: A Reflection of the Early Conflict between Courts of Law and Courts of Equity, ,Shakespeare Quarterly” 15/4, s. 371-375.

Marzec Ł. 2003. Civil Lawyers w Anglii Tudorów $i$ wczesnych Stuartów. Ze studiów nad prawem rzymskim w Anglii, „Czasopismo Prawno-Historyczne” LV/2, s. 213-230.

- 2005. Kilka uwag o Sądzie Kanclerskim i systemie equity w Anglii, ,Zeszyty Prawnicze UKSW" 5/1, s. 195-212.

- 2008. Czy prawo rzymskie pokonało kanat La Manche? „Krakowskie Studia z Historii Państwa i Prawa" 2, s. 43-54.

- 2015. Między Rzymem, Dunajem a Murem Hadriana. Prawo rzymskie i Europa w De Usu et Authoritate Iuris civilis Romanorum in Dominiis Principum Christianorum (1653) Arthura Ducka, Kraków: Księgarnia Akademicka.

Michałowska K. 1996. Trust i stosunki powiernicze w prawie angielskim, „Kwartalnik Prawa Prywatnego" 2, s. 293-341.

Moelwyn Merchant W. 1967. Commentary, w: W. Moelwyn Merchant (red.), William Shakespeare. The Merchant of Venice, London: Penguin Books, s. 163-207.

Myrczek E. 2005. Dictionary of Law Terms. English-Polish, Polish-English, Warszawa: C.H. Beck.

Oleck H.L. 1951. Historical Nature of Equity Jurisprudence, „Fordham Law Review” 20/1, s. 23-44.

Phelps C.E. 1902. Falstaff and Equity: An Interpretation, Boston-New York: Houghton Mifflin.

Phillips O.H. 1972. Shakespeare and the Lawyers, London: Methuen.

Pollock F., Maitland F.W. 1898. The History of English Law before the Time of Edward I, vol. 2, Cambridge: Cambridge University Press.

Posner R.A. 2013. Law and Commerce in The Merchant of Venice, w: B. Cormack, M.C. Nussbaum, R. Strier (red.), Shakespeare and the Law: A Conversation among Disciplines and Professions, Chicago-London: University of Chicago Press, s. 147-155.

Raffield P., Watt G. 2008. Shakespeare and the Law, Oxford-Portland, Oregon: Hart Publishing.

Ramjohn M. 2019. Unlocking Equity and Trusts, London-New York: Routledge.

Savenets A. 2011. Poetyzacja jako strategia tlumaczenia dramatów Szekspira w praktyce dwudziestowiecznych thumaczy ukraińskich, w: I. Kasperska, A. Żuchelkowska (red.), Przektad jako produkt i kontekst jego odbioru, Poznań: Wydawnictwo Rys, s. $255-270$.

Sokol B.J. 1992. The Merchant of Venice and the Law Merchant, „Renaissance Studies” 6/1, s. 60-67.

Sokol B.J., Sokol M. 1999. Shakespeare and the English Equity Jurisdiction: The Merchant of Venice and the Two Texts of King Lear, „The Review of English Studies” 50/200, s. 417-439.

- 2004. Shakespeare's Legal Language: A Dictionary, London-New York: Continuum.

- 2006. Shakespeare, Law, and Marriage, Cambridge: Cambridge University Press. 
Vetulani A. 1925. Pozew sadowy w średniowiecznym procesie polskim, Kraków: PAN.

Wall D.S. 1998. The Chief Constables of England and Wales: The Socio-legal History of a Criminal Justice Elite, London-New York: Routledge.

Watts C. 2006. Notes on The Merchant of Venice, w: C. Watts (red.), William Shakespeare. The Merchant of Venice, Hertfordshire: Wordsworth Classics, s. 109-122.

Weisberg R.H. 1998. Antonio's Legalistic Cruelty: Interdisciplinarity and The Merchant of Venice, „College Literature” 25/1, s. 12-20.

— 2008. The Concept and Performance of ,The Code" in The Merchant of Venice, w: P. Raffield, G. Watt (red.), Shakespeare and the Law, Oxford-Portland, Oregon: Hart Publishing, s. 289-298.

Woolfson J. 1998. Padua and the Tudors: English Students in Italy, 1485-1603, Cambridge: James Clarke.

Zachariasiewicz M. 2016. Trust $i$ inne stosunki powiernicze $w$ prawie porównawczym i prawie prywatnym międzynarodowym, Katowice: Wydawnictwo Uniwersytetu Śląskiego.

Zajda A. 2001. Studia z historii polskiego słownictwa prawniczego i frazeologii, Kraków: Wydawnictwo Uniwersytetu Jagiellońskiego. 